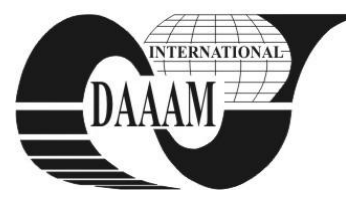

Annals of DAAAM for 2011 \& Proceedings of the 22nd International DAAAM Symposium, Volume 22, No. 1, ISSN 1726-9679 ISBN 978-3-901509-83-4, Editor B. Katalinic, Published by DAAAM International, Vienna, Austria, EU, 2011 Make Harmony between Technology and Nature, and Your Mind will Fly Free as a Bird Annals \& Proceedings of DAAAM International 2011

\title{
INVESTIGATION OF LUNG FUNCTION AMONG DENTAL LABORATORY TECHNICIANS
}

\author{
BOLOS, A[drian]; BORTUN, C[ristina] M[aria]; BOLOS, O[tilia] - C[ornelia] \& CERNESCU, A[nghel]
}

\begin{abstract}
Occupational exposures of dental laboratory technicians (inhalation of dusts from grinding and polishing of alloys, resins, ceramics, and disturbance of olfaction by methylmethacrylate monomer) may have adverse effects on their health. The study's objective is to analyze the lung function of dental laboratory technicians and to assess the influence of air quality from dental technology laboratories on it. The lung function was appreciated by spirometric testing (Cosmed Pony FX Desktop Spirometer,), with help of 2 parameters: forced vital capacity $(F V C)$ and forced expiratory flow in one second $\left(F E V_{l}\right)$. The results show that, duration of employment, hence occupational exposure is associated with a decrease in $\mathrm{FEV}_{\mathrm{l}} / \mathrm{FVC}$ ratio.
\end{abstract}

Key words: dental laboratory technician, lung function, spirometric testing, occupational exposure

\section{INTRODUCTION}

Dental laboratory technicians have multiple occupational exposures, which may have adverse effects on their health. The potential occupational risk factors include chemical, physical, ergonomic and other job-related factors (OSHA Occupational Health and Safety Administration, 2002). The health effects of concern include: potential adverse respiratory effects from inhalation of dusts from grinding and polishing of metal alloys, resins, ceramics, plaster, and the abrasives used for polishing (Choudat, 1994), (Parks et al., 1999), (Kelleher et al., 2000) or acrylates (Nayebzadeh et al., 2000); dermatitis from contact with acrylates and metals or disturbance of olfaction by methyl methacrylate (MMA) monomer and health complaints caused by noises, vibration of hand pieces, and long working hours (Jacobsen et al., 1996).

Several studies have examined the effects of occupational exposures on respiratory health in dental technicians. Choudat (1994) reported no significant differences in lung function and prevalence of respiratory symptoms between dental technicians and controls, but an increased risk of pneumoconiosis among dental technicians and a positive interaction between occupational exposure and cigarette smoking. Selden et al. (1995) found that 6 out of 37 dental technicians with at least 5 years of exposure to dust from cobalt-chromium-molybdenum alloys had pneumoconiosis. This study group also had lower lung function than the expected values. A study by Radi et al. (2002), reported that dental technicians had significantly lower percent- predicted values in forced vital capacity and maximal flow rates at $25 \%$ and $50 \%$, respectively, than did controls.

The effects of occupational exposures on respiratory symptoms or lung function of Romanian dental technicians were not consistently reported in previous studies. The associations between dust exposure and lung function among Romanian dental technicians deserves further clarification.

The aim of this study was to measure the lung function of dental technicians and to assess the connection between occupational exposures to particulate matter and MMA monomer and lung function of dental technicians.

\section{METHOD}

Spirometric testing represents an investigation, which examines if the respiratory capacity of a person/patient is affected. By spirometric testing, one measures the inhaled and exhaled air volume, in a certain time lapse. The spirometric parameters of interest are forced vital capacity (FVC), forced expiratory flow in 1 second $\left(\mathrm{FEV}_{1}\right)$ and $\mathrm{FEV}_{1} / \mathrm{FVC}$ ratio. $\mathrm{FVC}$ represents the exhaled air volume, as fast as the patient can, while $\mathrm{FEV}_{1}$ appreciates the air volume exhaled in one second. During investigation the doctor recommends the patient to inhale deep, then to blow/exhaust into a tube connected to a device called spirometer, as intense as he/she can.

This study included repeated measurements of lung function of dental technicians. 20 dental technicians from different laboratories in Timisoara were invited to participate in this study. A baseline questionnaire survey was used to collect information regarding workers' occupational history, habits, respiratory symptoms and demographics. A written informed consent was obtained from each participating subject.

For each dental technician participating in this study, the lung function was measured on six occasions: at the beginning and at the end of the shift on Monday, Wednesday and Friday. For these measurements, Cosmed Pony FX Desktop Spirometer was used. Forced expiratory maneuvers were performed in a standing position. For each subject, trials were taken until three acceptable trials were obtained or a maximum of eight trials was reached.

Next to be performed is the evaluation of air quality from dental laboratories, by ambient air sampling for MMA, particulate matter and base metals.
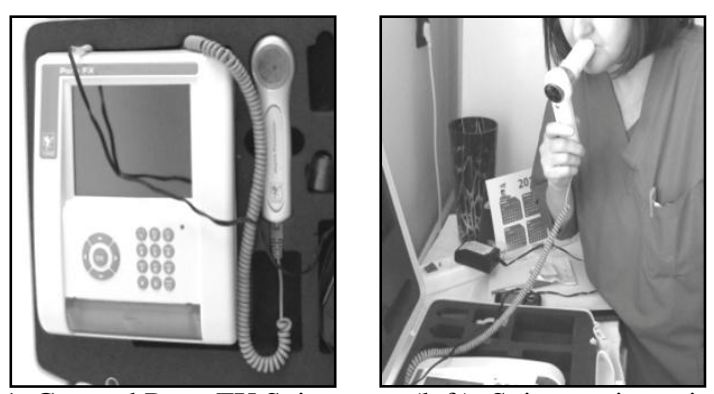

Fig.1. Cosmed Pony FX Spirometer (left); Spirometric testing (right)
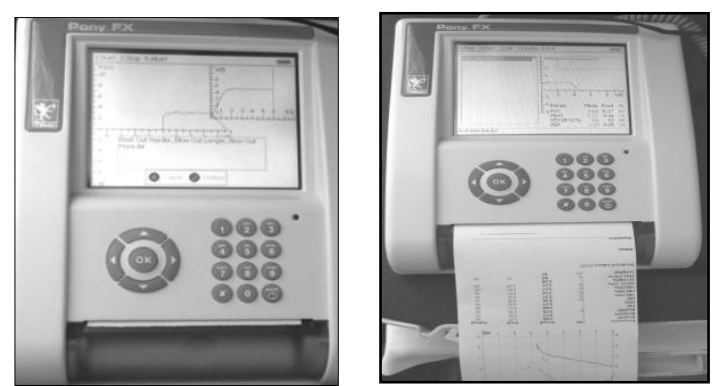

Fig.2. Aspects during the spirometric testing 


\section{RESULTS}

20 dental technicians from different laboratories in Timisoara participated to this study.

Table 1 shows characteristics of the dental technicians, who participated at the spirometric testing. Thirty percent of the workers were current smokers. The average duration of employment as a dental technician was 7 years. According to the questionnaire, the dust collectors were used by $80 \%$ of the workers.

Means of lung function parameters for the participating workers before-shift and after-shift on Friday are presented in Table 2. Both before- and after-shift the $\mathrm{FEV}_{1} / \mathrm{FVC}$ ratio was significantly lower for the workers employed for more than 10 years, although precent-predicted $\mathrm{FVC}$ and $\mathrm{FEV}_{1}$ appeared to be higher at workers with more than 10 years of employment. Moreover, when workers were stratified by cigarette smoking status, means of lung function parameters, before-shift or aftershift, there were no significant differences between current/former smokers and non-smokers.

Our results indicate a direct connection between the lung function of dental technicians and their occupational exposureworkplace air quality.

\begin{tabular}{|c|c|}
\hline \multicolumn{2}{|l|}{ Variables } \\
\hline $\mathrm{N}$ & 20 \\
\hline Age (years)- mean & 30 \\
\hline \multicolumn{2}{|l|}{ Sex, n (\%) } \\
\hline Male & $15(75)$ \\
\hline Female & $5(25)$ \\
\hline \multicolumn{2}{|l|}{ Cigarette smoking, n (\%) } \\
\hline Current smoker & $6(30)$ \\
\hline Former smoker & $2(10)$ \\
\hline Never & $12(60)$ \\
\hline Duration of employment (years) & 7 \\
\hline \multicolumn{2}{|l|}{ Job contents } \\
\hline Making crowns and bridges, $\mathrm{n}(\%)$ & $11(55)$ \\
\hline \multicolumn{2}{|l|}{ Making removable partial dentures } \\
\hline Metal framework, $\mathrm{n}(\%)$ & $4(20)$ \\
\hline Resin part, $\mathrm{n}(\%)$ & $4(20)$ \\
\hline Making complete denture, $\mathrm{n}(\%)$ & $4(20)$ \\
\hline Making orthodontic appliances, $\mathrm{n}(\%)$ & $1(5)$ \\
\hline \multicolumn{2}{|l|}{ Use of dust control equipments } \\
\hline Dust collector, n $(\%)$ & $16(80)$ \\
\hline Polish or grinding in a boxglove, $\mathrm{n}(\%)$ & $4(20)$ \\
\hline \multicolumn{2}{|l|}{ Use of personal protective equipments } \\
\hline Plastic face shields, $\mathrm{n}(\%)$ & $13(65)$ \\
\hline Cotton or paper mask, $\mathrm{n}(\%)$ & $15(75)$ \\
\hline Gloves, $\mathrm{n}(\%)$ & $1(5)$ \\
\hline
\end{tabular}

Tab. 1. Characteristics of the studied dental laboratory technicians

\begin{tabular}{|l|l|l|l|}
\hline $\begin{array}{l}\text { Lung function } \\
\text { parameters }\end{array}$ & $\begin{array}{l}\text { All } \\
\text { workers }\end{array}$ & $\begin{array}{l}>10 \text { years of } \\
\text { employment }\end{array}$ & $\begin{array}{l}<10 \text { years of } \\
\text { employment }\end{array}$ \\
\hline N & 20 & 5 & 15 \\
\hline Before-shift \\
\hline FVC & 99.35 & 103.64 & 95.55 \\
\hline FEV $_{1}$ & 102.44 & 105.40 & 100.29 \\
\hline FEV $_{1} /$ FVC\% & 86.81 & 81.96 & 88.26 \\
\hline After-shift \\
\hline FVC & 98.75 & 101.45 & 96.10 \\
\hline FEV $_{1}$ & 100.74 & 104.16 & 99.63 \\
\hline FEV $_{1} /$ FVC\% & 86.94 & 83.16 & 87.92 \\
\hline
\end{tabular}

Tab. 2.Mean pulmonary function measured on Friday for all participating workers and stratified by duration of employment $(\mathrm{P}<0.05$, two-sided t-test for comparison of means between workers with $>10$ versus $<10$ years of employment.)

\section{CONCLUSION}

This study appreciated the lung function of dental technicians in Timisoara. The results appear to be consistent with previous reports of adverse effects of the occupational exposure on pulmonary function of dental technicians (Radi et al., 2002), (Suh-Woan et al., 2006).

Use of local exhaust ventilation system decreased the levels of acrylic dust in dental laboratories.We also recorded that the dust collector was not used during all the polishing and grinding procedures. Continuing education about proper use of dust collecting system has been proposed for these dental technicians.

Nevertheless, duration of employment, hence occupational exposure was associated with a significant decrease in lung function.

This study is a start line for future research regarding the influence of workplace air quality on the health of dental technicians. The next step would be the determination of concentrations of MMA and elements in particles.

\section{ACKNOWLEDGEMENTS}

This work was supported by by Project POSDRU/107/1.5/S 178702 (2011), financed from European Social Fund- "InterUniversities Partnership for Increasing the Quality and Interdisciplinary $\mathrm{PhD}$ Medical Research through $\mathrm{PhD}$ Scholarships- DocMed.net" and by CNCSIS-UEFISCSU IDEI grant, ID 1878/2008, contract no. 1141/2009.

\section{REFERENCES}

Choudat D. (1994). Occupational lung diseases among dental technicians, Tubercle Lung Disease, vol.75, pp99-104, ISSN 0962-8479

Jacobsen N.; Derand T.; Hensten-Pettersen A. (1996). Profile of work-related health complaints among Swedish dental laboratory technicians, Community Dentistry and Oral Epidemiology, vol.24, pp138-144, ISSN 1600-0528

Kelleher P.; Pacheco K.; Newman L.S. (2000). Inorganic dust pneumonias; the metal-related parenchymal disorders, Environmental Health Perspectives, vol.108, Suppl 4, pp685-696, ISSN: 0091-6765

Nayebzadeh A.; Stangel I.; Dufresne A. (2000). Risk of respiratory exposure of dental personnel to amalgam alternatives, Science of the Total Environment, vol.247, pp33-39, ISSN 0048-9697

OSHA Occupational Health and Safety Administration (2002) US Department of Labor. Preventing adverse health effects from exposure to beryllium in dental laboratories, Hazard Information Bulletins, HIB 02-04-19 (rev.05-14-02), ISSN 0267-7261

Parks C.G.; Conrad K.; Cooper G.S. (1999). Occupational exposure to crystalline silica and autoimmune disease, Environmental Health Perspectives, vol.107, Suppl 5, pp793-802, ISSN 0091-6765.

Radi S.; Dalphin J.C.; Manzoni P.; Pernet D.; Leboube M.P.; Viel J.F. (2002). Respiratory morbidity in a population of French dental technicians, Journal of Occupational and Environmental Medicine, vol.59, pp398-404, ISSN: 10762752

Selden A.I.; Persson B.; Bornberger-Dankvardt S.I.; Winstrom L.E.; Bodin L.S. (1995). Exposure of cobalt chromium dust and lung disorders in dental technicians, Thorax, vol.50, pp769-772, ISSN 1468-3296

Suh-Woan H.; Yuh-Yih L.; Tzu-Chin W.; Chun-Cheng H.; Chang-Chuan C.; Shih-Chun C.L. (2006). Workplace air quality and lung function among dental laboratory technicians, American Journal of Industrial Medicine, vol.49, pp85-92, ISSN 1097-0274 